\title{
ANALYSIS OF STUDENT TRANSPORTATION NEEDS AT UNIVERSITAS GADJAH MADA
}

\author{
Rifda Galuh Kusuma $^{1 *}$, Rini Rachmawati ${ }^{1}$ \\ ${ }^{1}$ Urban Development Research Group, Department of Development Geography, Faculty of \\ Geography, Universitas Gadjah Mada
}

(Received: November 2020 / Revised: November 2020 / Accepted: December 2020)

\begin{abstract}
Universitas Gadjah Mada (UGM) in Indonesia brings thousands of new students annually. This greatly affects the use of transportation modes and the need for modes of transportation to the campus. This study aims to determine the modes of transportation used by students to campus, factors that influence the choice of transportation modes, and the needs of student transportation modes. This study uses a quantitative approach with descriptive analysis and Cramer's V correlation test. The results of the study show that the transportation modes used by Universitas Gadjah Mada's students as a means of transportation to the campus are mostly private $(70.5 \%)$. Factors that influence the choice of modes of transportation are private vehicle ownership, driving license ownership, monthly allowance, residence, frequency of use of transportation modes, time of movement, distance traveled, transportation modes changing, travel time, transportation costs, security/safety, timeliness, and speed. The modes of transportation needed by students are motorbikes and online transportation/ride-hailing service. The transportation characteristics that are most needed by students are fast, cheap, and comfortable. As many as $89.4 \%$ of students agreed and as many as $10.6 \%$ of students did not agree if there were vehicles provided by the campus.
\end{abstract}

Keywords: Modal choice; Student transportation; Transportation needs; Universitas Gadjah Mada

\section{INTRODUCTION}

Transportation is the basis for economic and community development and the growth of industrialization (Banerjee et al., 2020; Cervero, 2013). Transportation is the activity of moving goods (cargo) and passengers from one place to another (De Vos \& Witlox, 2013; Ferrari et al., 2014). The need for mobility requires attention in various studies of the development or planning of the transportation system in an area. However, it should be noted that the increase in movement is influenced by regional / population development, especially in urban areas which turned out to be unable to respond properly to the management or planning of the transportation system, which eventually led to regional problems such as congestion (Primasari et al., 2013).

The transportation sector is one of the most important and strategic sectors in the development of a region. Transportation can be seen in two categories. First, the transfer of materials and production results using a conveyance. Second, transporting passengers from one place to another (De Vos \& Witlox, 2013; Ferrari et al., 2014).

\footnotetext{
*Corresponding author's email: rifda.galuh.k@mail.ugm.ac.id, rinirachma@ugm.ac.id DOI: https://doi.org/10.32783/csid-jid.v3i2.174
} 
The role of transportation can be seen in terms of economic, social, political, and environmental (Banister et al., 2011; Glaeser et al., 2008; Glaeser \& Ponzetto, 2018; Steg \& Gifford, 2005). To meet the needs (demand) for transportation services, transportation facilities (supply) must be provided in an amount of capacity that is in balance with what is needed. Planning for transportation needs to consider economic, social, and environmental problems (Banister et al., 2011; Shaheen \& Chan, 2016).

Urbanization can be demonstrated through changes in population density, changes in the built environment, and urban sprawl processes (Rachmawati, 2005; Ramachandra et al., 2015). The phenomenon of urbanization in suburban areas can be explained in the urban areas of Yogyakarta. Urbanization in the suburbs of Yogyakarta City has been rapid, especially in the northern part of Yogyakarta City, Sleman Regency. In this section, there are many new settlements, supermarkets, and campuses. One of the biggest universities in Yogyakarta and even in Indonesia, namely Universitas Gadjah Mada (UGM). Each year UGM brings thousands of new students from various regions in Indonesia. In the 2018/2019 school year, Universitas Gadjah Mada received 9,125 new students (Universitas Gadjah Mada, 2018). The increasing number of students each year will certainly greatly affect the use of transportation modes and the need for transportation modes to campus.

Realizing the educopolis area is one of the visions developed in the Campus Development Master Plan at Universitas Gadjah Mada, Indonesia. This is a step taken by the university in creating a conducive environment for the learning process to take place. This effort was taken in the context of developing multidisciplinary collaboration and responsiveness to ecological issues in order to achieve the University's vision. However, efforts to realize the educopolis campus in terms of transportation so far are only limited to the existence of campus bicycles. The handling of other transportation is deemed not fulfilling.

Tamin (2000) argued that factors affecting the choice of transportation mode are divided into (1) characteristics of road users (availability or ownership of private vehicles, driving license ownership, household structure, income, and other factors), (2) characteristics of movement (purpose of movement, time of movement, and travel distance), and (3) characteristics of modes of transportation (travel time, transportation costs, availability of space and parking rates, as well as qualitative factors that are difficult to calculate, such as comfort, reliability, and timetable, etc.). This study aims to determine the modes of transportation used by students to campus, factors that influence the choice of transportation modes, and the needs of student transportation modes.

Some of the previous studies related to transportation carried out by students, including research conducted by Pasha et al (2015). The study results show that $26 \%$ of students use public buses and only $5 \%$ use trains. In addition, $16 \%$ used a car and $12 \%$ used a private taxi. The reasons for students limiting the use of public transportation are poor service, inconvenience, bad and inadequate waiting rooms. Another study conducted by Primasari et al. (2013) states that the variables of travel time, travel costs, distance traveled, and the intensity of changing modes of transportation are variables that influence students in choosing the mode of transportation to the Universitas Brawijaya campus. Meanwhile, research conducted by Nugrayolanda (2016) states that motorbikes are the most effective transportation. Six factors were found that influenced students in choosing the mode of transportation, namely settlement density, residential location, road conditions in occupancy, travel time, vehicle ownership, and satisfaction using transportation. 


\section{METHODS}

This research used a quantitative approach to generate the findings. Data were collected by interview using a questionnaire to respondents' namely new Universitas Gadjah Mada students in the 2018/2019 school year. This is due to the 2018 students who are new students who are still adjusting or adapting to the new environment at Universitas Gadjah Mada. The sampling method used in each research object is to use the Probability Sampling method. The method of taking samples of respondents in each research object is done by using a sampling area to select the faculty to be sampled. Then to select respondents using proportionate stratified random sampling (Corbin \& Strauss, 2012; Emmel, 2014).

This study took samples in four faculties, namely the Faculty of Geography, the Faculty of Pharmacy, the Faculty of Psychology, and the Faculty of Animal Science. Data processing techniques using the method of editing, coding, and tabulation. Data analysis techniques used in this study are descriptive statistical analysis, Cramer or Cramer's V or Cramer Contingency Coefficient correlation analysis, and frequency distribution.

\subsection{Number of Samples}

The number of sample members is often expressed by the sample size. The number of samples must be representative of the population, which is the same as the character of the population. The greater the number of samples approaching the population, the smaller the chance of error and vice versa (Corbin \& Strauss, 2012; Emmel, 2014). So in this study researchers used an error rate of $5 \%$ so that the chance of errors getting smaller.

Table 1. Number of population and sample

\begin{tabular}{ccc}
\hline Faculty & Population & Sample \\
\hline Geography & 279 & 73 \\
Pharmacy & 218 & 57 \\
Psychology & 241 & 63 \\
Animal & 274 & 72 \\
Science & 1012 & 265 \\
Total & & \\
\hline
\end{tabular}

The formula for determining the number of samples from known population numbers in the formula below, and the error level of 5\%, then the number of respondents can be determined that is 265 respondents.

Formula to find out the number of samples from each faculty:

$$
R x=\frac{F x . S}{\mathrm{~N}}
$$

Where:

Rx: Number of faculty respondents $x$

Fx: Number of faculty students $x$

$\mathrm{S}$ : Number of samples

$\mathrm{N}$ : Total number of students (population) 


\section{RESULTS AND DISCUSSION}

\subsection{Characteristics of Selection of Mode of Transportation to Campus}

Based on the data in table 2 it is known that male respondents numbered 62 students $(23 \%)$ and female amounted to 203 students (77\%). In addition, the largest number of respondents was at the age of 18 years $(45 \%)$. Then the next largest number of respondents was at the age of 19 years (43\%), 20 years $(7 \%), 17$ years $(4 \%)$, and 16 years $(1 \%)$.

The modes of transportation in this study are divided into 2 (two), namely private transportation (on foot/walking, bicycle, motorcycle, and car) and public transportation (city bus, Trans Jogja, and ride-hailing service). Based on Figure 2, that the most used modes of transportation for UGM students are motorcycle (59\%) and ride-hailing service (24\%). The most common reason is that a motorcycle can meet the aspects of speed, timeliness, convenience, and cheaper price. The mode of ride-hailing service was also quite widely used as a means of transportation of students to campus because ride-hailing service can provide convenience, comfort, and security.

Table 2. Gender distribution of respondents in each faculty

\begin{tabular}{ccc}
\hline Faculty & \multicolumn{2}{c}{ Number of Respondents } \\
\cline { 2 - 3 } & Male & Female \\
\hline Geography & 19 & 54 \\
Pharmacy & 5 & 52 \\
Psychology & 8 & 55 \\
Animal & 30 & 42 \\
Science & & \\
\hline Total & 62 & 203
\end{tabular}

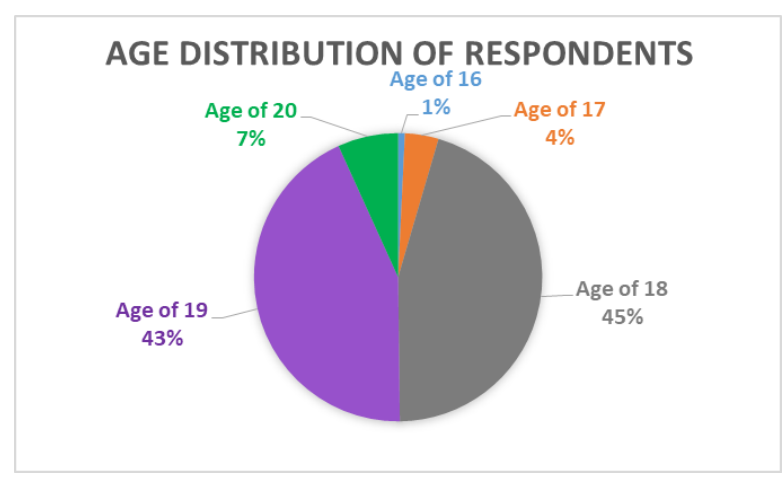

Figure 1. Age distribution of respondents

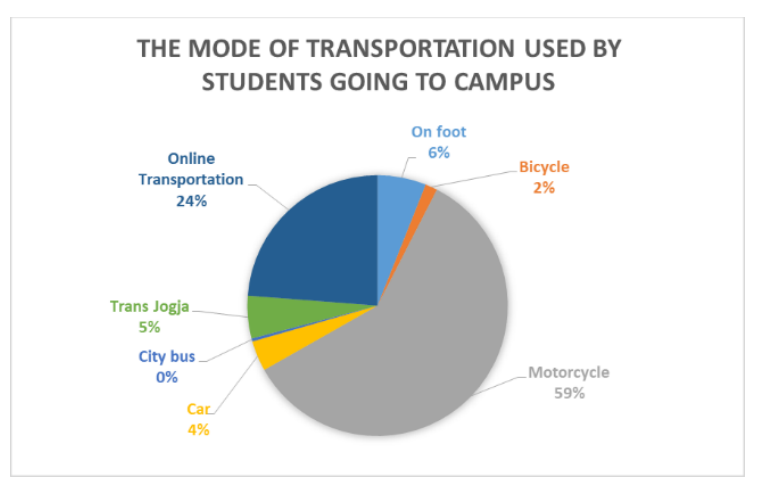

Figure 2. Transportation mode used by students toward campus

\subsection{Factors that Influence the Choice of Transportation Mode}

This study discusses the factors that influence the choice of transportation mode which adopts the concept as proposed by Tamin (2000). However, in this study, the factors that influence the choice of transportation mode by Universitas Gadjah Mada students are also divided into 3 characteristics, but by adding other factors as follows:

a. Characteristics of Road Users, which consist of private vehicles ownership, driving license ownership, and a monthly allowance 
b. Characteristics of Movement, which consist of student residence, the purpose of the movement, frequency of use of transportation modes, time of movement, distance traveled, and transportation modes changing for those using public transportation

c. Characteristics of Transportation Facilities, which consists of travel time, transportation costs, and qualitative factors (simplicity/ease, security/safety, convenience, availability, timeliness, speed of time, accessibility, and other factors).

The data analysis technique used to determine the factors that influence the choice of transportation mode is Cramer's V correlation test. The Cramer coefficient is an associative test when the nominal data scale with categories for each row and column is more than two (Yap \& Sim, 2011).

Table 3. The significance level of each variable using Cramer's V Correlation Test

\begin{tabular}{|c|c|c|c|c|}
\hline Dependent Variable & Independent Variable & $\begin{array}{c}\text { Asymptotic } \\
\text { Significance (2-sided) }\end{array}$ & $\begin{array}{l}\text { Chi-Square } \\
\text { Value }\end{array}$ & $\begin{array}{c}\text { Cramer's } \\
V\end{array}$ \\
\hline \multirow{28}{*}{$\begin{array}{c}\text { Selection of } \\
\text { Transportation Mode }\end{array}$} & \multicolumn{4}{|c|}{ Characteristics of Road User } \\
\hline & Private Vehicle Ownership & 0,000 & 269,172 & 0,411 \\
\hline & Driving License Ownership & 0,000 & 102,925 & 0,279 \\
\hline & Monthly Allowance & 0,034 & 30,423 & 0,196 \\
\hline & \multicolumn{4}{|c|}{ Characteristics of the Movement } \\
\hline & Residence & 0,000 & 57,964 & 0,270 \\
\hline & The Purpose of the Movement & 0,764 & 18,780 & 0,133 \\
\hline & $\begin{array}{c}\text { Frequency of Use of } \\
\text { Transportation Modes }\end{array}$ & 0,001 & 33,147 & 0,250 \\
\hline & Time of Movement & 0,022 & 32,059 & 0,201 \\
\hline & Distance Traveled & 0,000 & 62,552 & 0,281 \\
\hline & $\begin{array}{l}\text { Transportation Modes } \\
\text { Changing }\end{array}$ & 0,000 & 186,317 & 0,484 \\
\hline & \multicolumn{4}{|c|}{ Characteristics of Transportation Facilities } \\
\hline & Travel Time & 0,000 & 47,386 & 0,244 \\
\hline & Transportation Costs & 0,000 & 97,695 & 0,351 \\
\hline & Simplicity/Ease & 0,266 & 7,638 & 0,170 \\
\hline & Security/Safety & 0,000 & 35,118 & 0,364 \\
\hline & Convenience & 0,137 & 9,710 & 0,191 \\
\hline & Availability & 0,900 & 2,208 & 0,091 \\
\hline & Timeliness & 0,042 & 13,081 & 0,222 \\
\hline & Speed & 0,001 & 21,526 & 0,285 \\
\hline & Accessibility & 0,768 & 3,319 & 0,112 \\
\hline & There is nothing to deliver & 0,911 & 2,087 & 0,089 \\
\hline & Long distance & 0,472 & 5,576 & 0,145 \\
\hline & Efficient & 0,834 & 2,794 & 0,103 \\
\hline & Want to be healthy & 0,305 & 7,179 & 0,165 \\
\hline & Flexible & 0,973 & 1,266 & 0,069 \\
\hline & There is no other choice & 0,374 & 6,461 & 0,156 \\
\hline & $\begin{array}{l}\text { Public Transportation is } \\
\text { Limited }\end{array}$ & 0,911 & 2,087 & 0,089 \\
\hline
\end{tabular}

Based on table 3 above, that the factors that influence the choice of transportation modes are private vehicle ownership, driving license ownership, monthly allowance, residence, frequency of use of transportation modes, time of movement, distance traveled, transportation modes changing, travel time, transportation costs, security/safety, timeliness, and speed. This can be seen from the Asymptotic significance (2-sided) value of less than 0.05 which means that Ho is rejected and $\mathrm{Ha}$ is accepted. The strength of the relationship between the independent and dependent variables can be seen from the value of Cramer's $\mathrm{V}$ if approaching number 1 means 
the relationship is getting stronger, but if approaching number 0 means the relationship is getting weaker. Based on table 3, the factors that have a strong influence on the choice of transportation modes are private vehicle ownership and the transportation modes changing. Meanwhile, to find out the direction of the relationship, it is seen from the positive and negative signs in the contingency coefficient. If the direction of the relationship is positive, it means that the relationship is directly proportional, whereas if the direction of the relationship is negative, it means that it has an inversely proportional relationship.

\subsection{Transportations Needs of Universitas Gadjah Mada}

\subsubsection{Mode of Transportation Required by Students}

The modes of transportation needed by students are divided into 2 , namely private transportation and public transportation. Private transportation consists of on foot/walking, bicycle, motorcycle, and car. While public transportation consists of city buses, Trans Jogja, and ride-hailing service.

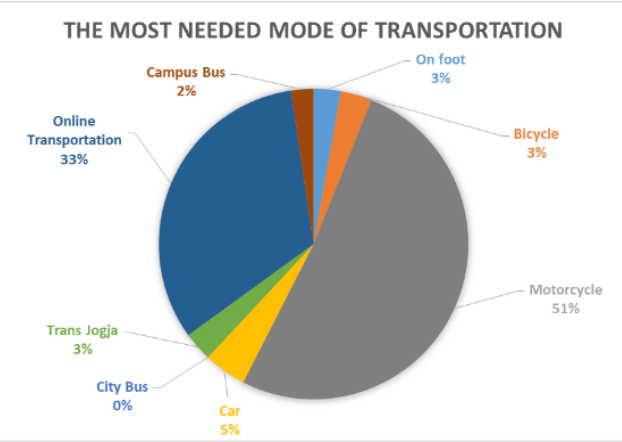

Figure 3. The most needed transportation modes for students toward campus

Based on Figure 3, the mode of transportation most needed by students is the motorcycle chosen by $51 \%$ of students. This is because most students have used bicycles as a means of transportation to campus. In addition, students also like to use motorbikes that are more effective and practical because they can avoid traffic jams, faster, and on time.

The second most needed mode of transportation is the ride-hailing service with a percentage of $33 \%$. The existence of a ride-hailing service can be a new transportation option for students, mostly for students who do not yet have a vehicle. Therefore, students can be facilitated by the presence of ride-hailing service that can help student mobility that is quite high. In addition, other features offered by ride-hailing service applications are also quite interesting to students, such as food delivery services and goods delivery services. Safety, punctuality, and speed are among the factors that influence students to choose ride-hailing service as the mode of transportation most needed to get to campus.

Another case with research conducted by Fraszczyk et al. (2019) in Salaya, Thailand states that $90 \%$ of respondents are willing to move to public metro transportation. The top four factors that will help facilitate the respondent's future move to the metro are: 'reliable schedule', 'good mode connectivity', 'seamless station - campus connection', and 'shorter travel times'. These results indicate that service reliability, connectivity, and time factors are very important for respondents in choosing the metro over other modes of commuter trips between Salaya and Bangkok in the future.

\subsubsection{Suitability of Transportation Needs}

Based on Figure 4, that as many as 234 students or about $88 \%$ of students feel it is suitable between the transportation that students use today with the transportation needs of students. However, there are still students who feel that it is not appropriate between the transportation used today and the transportation needs of students, as many as 31 students or $12 \%$. The reason 
most students already feel appropriate is that the transportation they use is fast, easy, and inexpensive. Meanwhile, the reason most students feel inappropriate between the transportation used today and the transportation needs of students is that the transportation they use is not convenient, expensive, and does not yet have a vehicle.

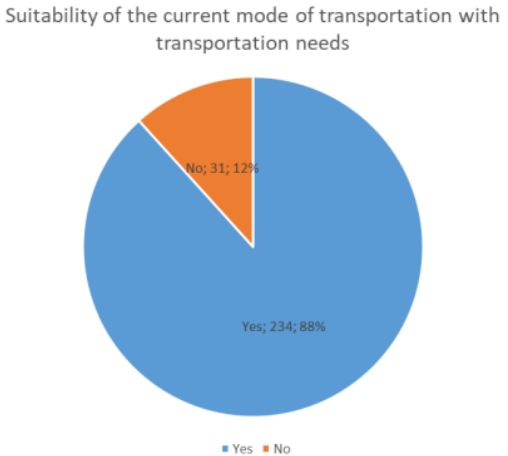

Figure 4. Graph of the suitability of the current mode of transportation with transportation needs

\subsubsection{Transportation Characteristics Needed by Students}

The transportation characteristics needed by students to get to campus are different from the modes of transportation needed by students. The characteristics of transportation required to mean the nature of the transportation students need, not the form or type of transportation mode required. 17 transportation characteristics are needed by students to get to campus. Based on Figure 5, the 3 most transportation characteristics needed by students are fast, cheap, and comfortable.

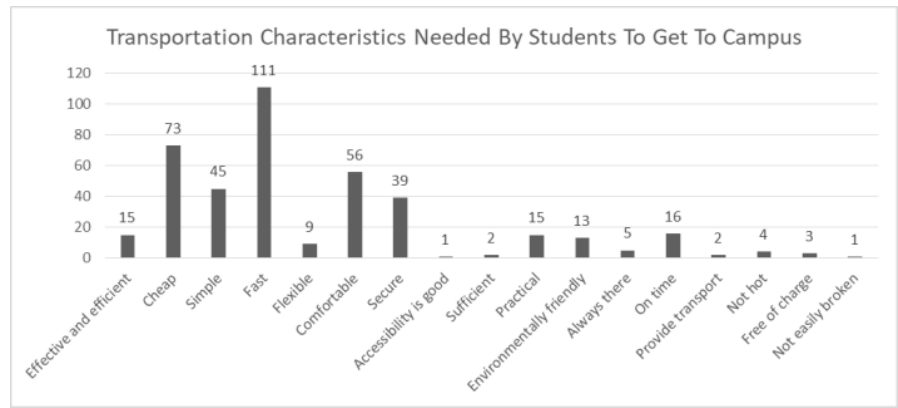

Figure 5. Transportation characteristics needed by students to campus

\subsubsection{Student Opinion If There Are Vehicles Provided By The Campus}

Student opinion if there are vehicles provided by the university/campus in this study is divided into 2 (two), namely agree and disagree. Then students can give reasons why students agree and disagree if there are vehicles provided by the university/campus.

Based on Figure 6, as much as $89 \%$ of students agreed and $11 \%$ of students disagreed if there were vehicles provided by the campus. This can be a suggestion or input for the campus to be able to provide vehicles or transportation for students both inside and outside the campus environment. The provision of vehicles from campus can certainly facilitate the mobilization of students, especially students who do not have a vehicle. 

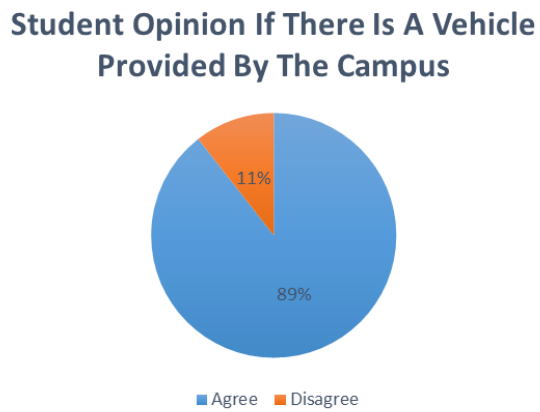

Figure 6. Graph of the student opinion if there is a vehicle provided by the campus

The most common reason given by students who agree with the existence of vehicles from campus is that it can facilitate students in mobilizing both inside and outside the campus environment. Another reason is that it can save transportation costs incurred. Students hope that vehicles from the campus will only be charged a low rate if using or not even being charged (free). The existence of a campus bus can increase the effectiveness of a sustainable environment by creating a greener and conducive environment on the university grounds (Hashim et al., 2013). Greening the campus must be a common core responsibility where all the academic community must play an active role in protecting the environment.

The most widely expressed opinion of students who disagree is that if the campus provides a vehicle for students, it will feel less effective and efficient, and requires a large budget. Another opinion states that the campus transportation is not necessarily following the needs of students, requires a long time, is less flexible, too troublesome, even some students believe that managing campus transportation will be difficult and not optimal, and the campus may not be able to provide vehicles for all students.

\section{CONCLUSION}

The modes of transportation used by Universitas Gadjah Mada students as a means of transportation to the campus are in the majority using private modes of transportation. Based on the results of the correlation, that the factors that influence the choice of transportation modes are private vehicle ownership, driving license ownership, monthly allowance, residence, frequency of use of transportation modes, time of movement, distance traveled, transportation modes changing, travel time, transportation costs, security/safety, timeliness, and speed. Factors that have a strong influence are private vehicle ownership and transportation modes changing.

The modes of transportation most needed by students are motorcycle (51\%) and ride-hailing service $(33 \%)$. The most transportation characteristics needed by students are fast, cheap, and comfortable. A total of 237 students $(89 \%)$ agreed if there were vehicles provided by the campus, and as many as 28 students (11\%) disagreed if there were vehicles provided by the campus.

\section{REFERENCES}

Banerjee, A., Duflo, E., \& Qian, N. (2020). On the road: Access to transportation infrastructure and economic growth in China. Journal of Development Economics, 145. https://doi.org/10.1016/j.jdeveco.2020.102442

Banister, D., Anderton, K., Bonilla, D., Givoni, M., \& Schwanen, T. (2011). Transportation and the environment. In Annual Review of Environment and Resources (Vol. 36, pp. 247-270). https://doi.org/10.1146/annurev-environ-032310-112100

Cervero, R. (2013). Linking urban transport and land use in developing countries. Journal of Transport and Land Use, 6(1), 7-24. https://doi.org/10.5198/jtlu.v6i1.425 
Corbin, J., \& Strauss, A. (2012). Basics of Qualitative Research (3rd ed.): Techniques and Procedures for Developing Grounded Theory. In Basics of Qualitative Research (3rd ed.): Techniques and Procedures for Developing Grounded Theory. https://doi.org/10.4135/9781452230153

De Vos, J., \& Witlox, F. (2013). Transportation policy as spatial planning tool; Reducing urban sprawl by increasing travel costs and clustering infrastructure and public transportation. Journal of Transport Geography, 33, 117-125. https://doi.org/10.1016/j.jtrangeo.2013.09.014

Emmel, N. (2014). Purposeful Sampling. In Sampling and Choosing Cases in Qualitative Research: A Realist Approach (pp. 33-44). https://doi.org/10.4135/9781473913882.n3

Ferrari, L., Berlingerio, M., Calabrese, F., \& Reades, J. (2014). Improving the accessibility of urban transportation networks for people with disabilities. Transportation Research Part C: Emerging Technologies, 45, 27-40. https://doi.org/10.1016/j.trc.2013.10.005

Fraszczyk, A., Weerawat, W., \& Kirawanich, P. (2019). Commuters' Willingness to Shift to Metro: a Case Study of Salaya, Thailand. Urban Rail Transit, 5(4), 240-253. https://doi.org/10.1007/s40864-019-00113-3

Glaeser, E. L., Kahn, M. E., \& Rappaport, J. (2008). Why do the poor live in cities? The role of public transportation. Journal of Urban Economics, 63(1), 1-24. https://doi.org/10.1016/j.jue.2006.12.004

Glaeser, E. L., \& Ponzetto, G. A. M. (2018). The political economy of transportation investment. Economics of Transportation, 13, 4-26. https://doi.org/10.1016/j.ecotra.2017.08.001

Hashim, R., Haron, S., Mohamad, S., \& Hassan, F. (2013). Assessment of Campus Bus Service Efficacy: An Application towards Green Environment. Procedia - Social and Behavioral Sciences, 105, 294-303. https://doi.org/10.1016/j.sbspro.2013.11.031

Nugrayolanda, F. (2016). Moda Transportasi yang Efetif dan Efisien bagi Mahasiswa ITB. Proceedings of the 2016 IPLBI Scientific Meeting.

Pasha, M. M., Chowdhury, I. M., \& Bhuiyan, M. A. A. (2015). University Student's Perception on Public Transit in Dhaka City. International Journal of Humanities and Social Sciences, 9(10).

Primasari, D., Ernawati, J., \& Wicaksono, A. (2013). Pemilihan Moda Transportasi Ke Kampus Oleh Mahasiswa Universitas Brawijaya. Indonesian Green Technology Journal, 2(2), 84-93.

Rachmawati, R. (2005). Urban and Peri-Urban Development - Structures, Processes and Solutions. Southeast Asian - German Summer School in Cologne/Germany.

Ramachandra, T. V., Bharath, A. H., \& Sowmyashree, M. V. (2015). Monitoring urbanization and its implications in a mega city from space: Spatiotemporal patterns and its indicators. Journal of Environmental Management, $148, \quad 67-81$. https://doi.org/10.1016/j.jenvman.2014.02.015

Shaheen, S., \& Chan, N. (2016). Mobility and the sharing economy: Potential to facilitate the first-and last-mile public transit connections. Built Environment, 42(4), 573-588. https://doi.org/10.2148/benv.42.4.573

Steg, L., \& Gifford, R. (2005). Sustainable transportation and quality of life. Journal of Transport Geography, 13(1 SPEC. ISS.), 59-69. https://doi.org/10.1016/j.jtrangeo.2004.11.003

Tamin, O. Z. (2000). Perencanaan dan Pemodelan Transportasi. In Perencanaan dan pemodelan transportasi.

Universitas Gadjah Mada. (2018). Mahasiswa Baru UGM Harus Jadi SANG JUARA. https://ugm.ac.id/id/berita/16767-mahasiswa.baru.ugm.harus.jadi.sang.juara

Yap, B. W., \& Sim, C. H. (2011). Comparisons of various types of normality tests. Journal of Statistical Computation and Simulation, 81(12), 2141-2155. https://doi.org/10.1080/00949655.2010.520163 